\title{
Essential Oils as Potential Control Agents Against Varroa Mite Varroa destructor Anderson and Trueman in Comparison with Chemical Substance on Honeybee Colonies Headed by Hybrid Local Egyptian Queens
}

\author{
M. F. Hassan", Margaret A. Rizk ${ }^{* *}$, Sally F. Allam* and A. Y. Zaki** \\ "Department of Zoology and Agricultural Nematology, Fac. of Agric., Cairo Univ. \\ *Plant Protection Research Institute, Agric. Res. Center, Min. of Agric
}

\begin{abstract}
The efficacy of essential oils i.e. geranium oil, lemon oil, mint oil, chamomile oil and black cumin oil, used alone or in mixtures, compared with a chemical insecticide, mitac, against Varroa mite was evaluated. The infestation levels of these substances were evaluated in honeybee colonies during October, November and December 2005 in Giza Governorate. Cotton strips, saturated with the tested substances, were hanged between the middle combs in all treatments. The efficacy rate of geranium oil, lemon oil, mixture of (geranium, lemon, chamomile and mint oils) and mixture of (lemon, black cumin and mint oils), in comparison with mitac was $37.27 \%, 32.56 \%, 37.59 \%, 36.27 \%$ and $53.64 \%$ respectively. This study indicates that using mixture of essential oils was more suitable with cotton strips in controlling Varroa mite. Genetic improvement by using hybrid queens between Apis mellifera carnica (drones) and Apis mellifera lamerkii (virgins), proved to be an effective and reliable method for the control of Varroa destructor. Cultural control by lemon oil or added to sugar solution was used in feeding the colonies, especially in winter. Putting the colonies in citrus garden and cultivation of geranium or chamomile around apiaries (these new cultural control) were added to IPM programmes for control Varroa mite.
\end{abstract}

Key Words: Varroa destructor, control, essential oils, mitac, cultural control, genetic improvement, Apis mellifera lamerkii.

\section{INTRODUCTION}

The parasitic mite Varroa destructor (Anderson and Trueman, 2000) is currently the most serious global threat to beekeeping because of the widespread of the western honeybee, Apis mellifra $L$., for honey production and crop pollination (De Jong et al., 1982 and De Jong 1997). Varroa jacobsoni Oud. was recorded for the first time in Egypt in 1983 (Wienands, 1988), and within the last few years the parasitic mite became a serious problem to beekeepers in the majority of the Egyptian Governorates causing economic losses to most beekeepers and destroying many apiaries (Abd El-Fattah et al.,1991).Control of Varroa mite is especially difficult as the majority of mites live inside the sealed brood for reproduction and are well protected from different methods of control (Hoppe et al., 1989). Using acaricides was effective against $V$. jacobsoni but their application within the hives tends to contaminate the wax and honey, also the mite can develop resistance against these chemicals (Ifantidis, 1987). On the other hand, some scientists used the essential oils to control this pest (Fathy\&Fouly,1993\&1995, El-Shemy et al.,1995, El-Shemy,1997 and Allam et al., 2003\&2004). Also, genetic control by using the local Egyptian race $A$. mellifera lamerckii is useful. Cross breeding between two geographical races especially with Egyptian race A.m. lamarckii was very impotant for future bees to tolerate diseases and help for difference in genetic structure in hybrids (Abo-Shady, 1939, Allam 1999 and Allam et al., 2004). Guzman et al. (1996) found that the European, Africanized and hybrid honeybees differed in susceptibility to Varroa infestation. They added that European brood was twice as attractive to female Varroa compared to Africanized brood. Bienefeld (1996) reported that reducing the duration of the length of the capped brood phase is considered to be a good approach for breeding honeybees resistant to $V$. jacobsoni. Allam et.al.(1999) found that hybrid stock from the Egyptian mother was most susceptible. The tolerance of stock has been attributed to cleaning movements, shorter post capping period, the durations of all biological aspects and behaviour. The hybrid between Egyptian virgin $\mathrm{x}$ hybrid Carniolan male, (the hybrid between Carniolan female $\mathrm{x} 1 s t, 2 n d, 3 r d$ Carniolan male and the Carniolan race Apis mellifera carnica). The genetic, in combination with cultural control can be recommended throughout the year to keep the population of Varroa mite under control and to avoid the contamination of honey and wax with the acaricides during the honey flow season. In contrast, using chemical control in combination with genetic control was the best way for controlling Varroa and strength of colonies. This last result can be recommended as a part in the program of integrated pest management during fall in high infestation of Varroa mite especially in big farms which use 
honeybees as pollinators. Therefore, this work was carried out to evaluate the efficacy of some essential oils (mint, chamomile, lemon, black cumin, geranium) compared with a chemical pesticide (mitac) in controlling the Varroa mite in colonies headed by hybrid Egyptian queens (A. mellifera lamerkii) mated with hybrid carniolan drones $(A$. mellifera canica) (H.L.H).

\section{MATERIALS AND METHODS}

Experiments for controlling Varroa mite were carried out during September-December 2005 in Giza Governorate (Kerdasa region) in private apiary. Thirty naturally infested honeybee colonies nearly similar in their strength and headed by hybrid Egyptian queens (A. mellifera lamerkii) mated with hybrid carniolan drones (A. mellifera carnica) (H.L.H) were used. The colonies were divided into six stocks $(5$ colonies as replicates for each treatment and 5 colonies as control). Preliminary tests were carried out to decide the appropriate dose of oils and its side effects on bees and queens.

\section{Tested materials:}

1- Geranium oil (Pelargonium graveolens, Geraniaceae).

2- Lemon oil (Citrus aurantifolia, Rutaceae).

3- Chamomile oil (Matricaria chamomilla, Compositae).

4- Common spearmint oil (Mentha spicata, Labiatae).

5- Black cumin oil (Nigella sativa, Umbelliereae) extracts of seeds.

6- Mitac® EC (An emulsifiable containing $20 \%$ w/v amitraz).

\section{Preparing essential oils and mixtures:}

1- Geranium oil was prepared by mixing $15 \mathrm{ml}$ oil with $0.5 \mathrm{ml}$ Triton-x (emulsifier) and sufficient water to obtain $100 \mathrm{ml}$ of solution.

2- Lemon oil was prepared by mixing $15 \mathrm{ml}$ oil with sufficient water to obtain $100 \mathrm{ml}$ of solution.

3- The first mixture was $5 \mathrm{ml}$ from each geranium, lemon, chamomile and mint with water added to obtain $100 \mathrm{ml}$ of solution.

4- The second mixture was $5 \mathrm{ml}$ lime, $5 \mathrm{ml}$ black cumin and mint oil with water added to obtain $100 \mathrm{ml}$ of solution.

5- Mitac (Amitraz) was prepared by mixing $5 \mathrm{ml}$ from mitac with sufficient water to obtain $100 \mathrm{ml}$ of solution.

\section{Experimental procedures:}

All colonies were treated with strips of cotton material $(20 \times 2.5 \mathrm{~cm} \times 5 \mathrm{~mm})$ saturated with oils $(15 \mathrm{ml})$ from solution. One cotton strip was hanged between middle combs every week in all treatments for 14 weeks.

\section{Assessment of the efficacy levels:}

The infestation levels in all experimented colonies were determined before and after each application, through the following data:

1- Number of dead mites fallen down on a white card board (coated with Vaseline) located under the colony.

2- Number of mites in random sample of approximately 100 live bees.

3 - Number of mites in 20 cells of each worker and drone brood (if available) or in 20 workers cells if drone brood was not available

4- The area of sealed worker brood (colony strength). The efficacy of the tested essential oils was calculated after each application according to the equation of Girdani and Leporati (1989):

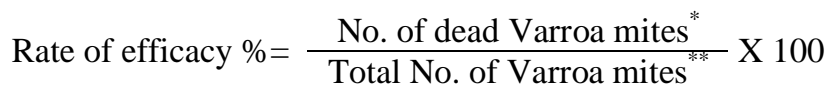

"Dropped mites as a result of the treatment + natural mortality

${ }^{* *}$ Dropped mites + natural mortality in control + No. of mites on 100 live bees + No. of mites in 20 cells of brood.

\section{RESULTS AND DISCUSSION}

Experimental data presented in table (1) show that:

\section{1- Geranium oil:}

The efficacy rate ranged from 19.7 to $47.79 \%$ (average: $37.27 \%$ ) through all treatments. Number of dead mites ranged from 5.8 to 33.9 mites /col. weekly (average: $18.44 \mathrm{mites} / \mathrm{col}$.).These results are similar to those of Allam et al. (2003) who used jasmine oil and found that the rate of efficacy ranged from 12.4 to $40.8 \%$ (average:22.4\%). Also, Ismail et al. (2006) used geranium oil in autumn $2000 \& 2001$ and found that infestation level on worker brood decreased significantly from $3.33 \%$ to $1.67 \%$ and infestation level on adult bees decreased significantly from $5.03 \%$ to $2.37 \%$. These agree with those of Allam et al. (2005), who recorded that the least range number of dead mites throughout the year 2000-2001 in El-Wasta (Beni-Suef governorate) was 1.8 to $134 \mathrm{mites} / \mathrm{col} . / \mathrm{month}$; these results may be due to the cultivation of geranium around bee hives.

\section{2- Lemon oil:}

The efficacy rate ranged from 21.57 to $45.22 \%$ (average: $32.56 \%$ ) through all treatments. Number of dead mites ranged from 8.2 to 34.4 mites/col. weekly (average: $19.74 \mathrm{mites} / \mathrm{col}$.). These results agree with those of Elzen et al. (2000) who used 


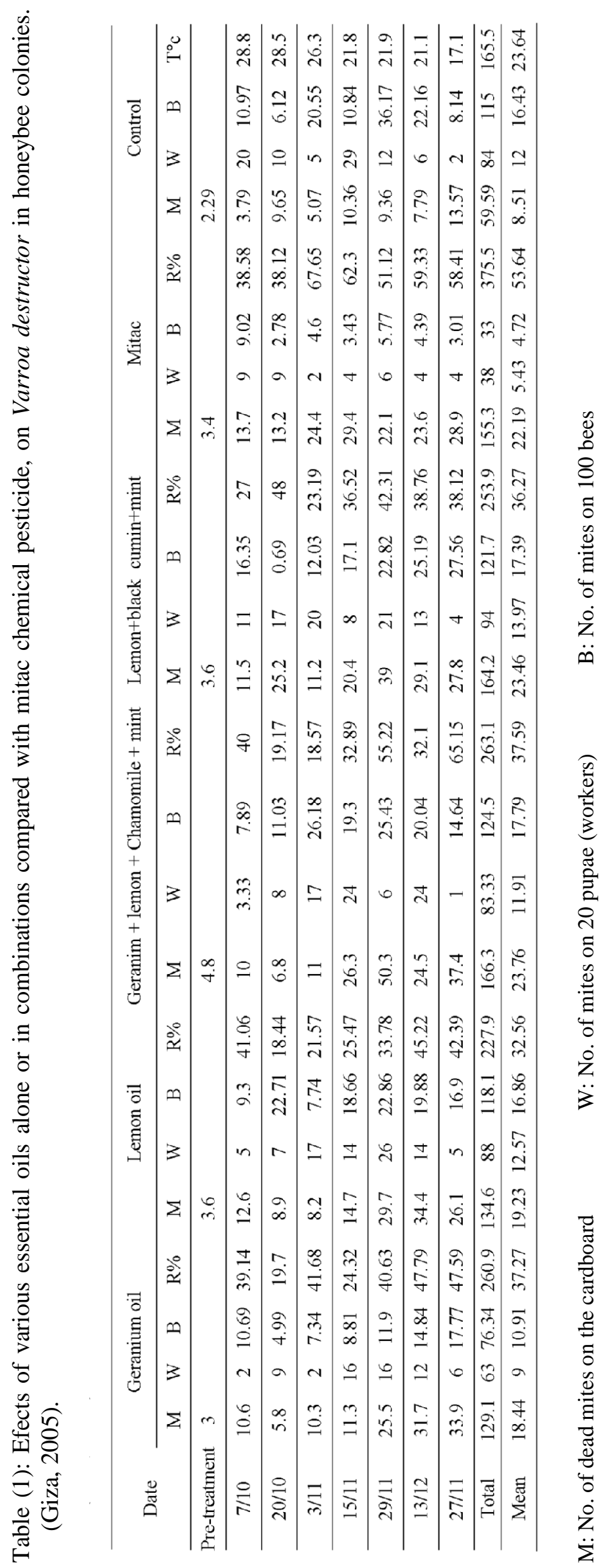


four essential oils found in citrus leaves (citral, limonene, citronellal and linalool) and found citral to be the most effective with $72.8 \%$ knockdown of mites from infested bees exposed to this compound. Clark (1997) who used Apilife-VAR pads (i.e., essential oils) in autumn 1995 and 1996, found that average efficacy was $80 \%$ and $82 \%$ respectively. However, addition of lemon oil or lemon juice to sugar solution led to decrease population of Varroa, as lemon has an effect on Varroa control. These results agree with those of Allam et al. (2004). This is a new method for cultural control of Varroa as a lot of beekeepers add lemon juice to sugar solution for more activities in honey bee colonies. In this study, a new function for this culture operation to decrease Varroa population was demonstrated.

\section{3- Mixture of geranium, lemon, chamomile and mint oils:}

The efficacy rate ranged from 18.57 to $65.15 \%$ (average: $37.59 \%$ ). Number of dead mites ranged from 6.8 to 50.3 (Table 1) mites/col. weekly (average: 23.67 mites/col.). These results could be compared with those of Allam et al. (2003). They used mixture of jasmine, neem and black cumin oils and reported that the efficacy rate ranged from 20.8 to $66.9 \%$ (average: $47.6 \%$ ) and found that the number of dead mites ranged from 18.3 to 158 mites/col. weekly (average: $44.20 \mathrm{mites} / \mathrm{col}$.). These results are supported by those of Allam et al. (2005) who recorded that the least range number of dead mites throughout the year in 2000-2001 was 3 to $76.7 \mathrm{mites} / \mathrm{col} / \mathrm{month}$, in Sennoris region (Fayoum governorate), due to chamomile (M. chamomilla) planted greatly around bee hives.

\section{4- Mixture of lemon, black cumin and mint oil:}

The efficacy rate ranged from 23.19 to $48 \%$ (average: $36.27 \%$ ). Number of dead mites ranged from 11.2 to 39 mites/col. weekly (average: 23.97 mites/col.). These results are in accordance with those of Allam et al. (2004). They used smoking with fresh leaves of eucalyptus and dry leaves of mint and reported that the efficacy rate ranged from 37 to $83 \%$ with an average of $57 \%$ and the number of dead mites ranged from 15.5 to 113.5 mites/col. weekly. Also, Allam et al. (2003) used mixture of mavrik, jasmine and black cumin oils and found that the efficacy rate ranged from 11.3 to $80.9 \%$ (average: $38.2 \%$ ) and reported that the number of dead mites ranged from 7.7 to 59.3 mites/col. weekly (average : 24.7 mites/col.).

\section{5- Mitac:}

The efficacy rate ranged from 38.12 to $67.65 \%$ (average: $53.64 \%$ ). Number of dead mites ranged from 13.2 to 29.4 mites/col. weekly (average: 22.67 mites/col). These results are in agreement with those of Baxter et al. (1999) who used Apivar (amitraz $500 \mathrm{mg} / \mathrm{strip}$ ) in plastic strips and found Varroa mortality $97.99 \%$, and an increase mortality of 1-3 day old larvae $61 \%$ vrs. $83 \%$ for control. Kumova (2001) used Amitraz (vamitrat, on paper strips) and found it $91.1 \%$ effective on Varroa jacobsoni.

\section{Overall comparison:}

The comparative results of geranium oil, lemon oil, the first mixture of geranium, lemon, chamomile and mint, the second mixture of lemon, black cumin and mint and the last suspension was mitac for controlling Varroa mites could be summarized in the points:

- Fluctuations were noted in the efficacy rate between applications. The efficacy of all treatments during the first and second applications ranged from 18.44 to $48.00 \%$, while ranged from 18.57 to $67.65 \%$ for the third, fourth and fifth applications. It ranged from 32.1 to $65.15 \%$ for the sixth and seventh applications. These fluctuations may be due to higher temperature in the first month $\left(28.5-28.8^{\circ} \mathrm{C}\right)$ than in the second month $\left(21.8-26.3{ }^{\circ} \mathrm{C}\right)$ and the third month $\left(17.1-21.1^{\circ} \mathrm{C}\right)$. Temperature could act as a biotechnical treatment against Varroa mites as high temperatures negatively affect its activities. On the other hand, these ranges of temperature were optimum for mite reproduction. These results agree with those of El-Shemy et al. (2001) who found that the higher efficacy of natural materials in 1996 than in 1997 could be due to the higher temperature in the former $\left(34-4{ }^{\circ} \mathrm{C}\right)$ than in the latter year $\left(31-35^{\circ} \mathrm{C}\right)$. Also, Allam et al. (2003) found that fluctuations were noted in the efficacy rate between applications and recorded that these fluctuations may be due to higher temperature in the first month $\left(32-36^{\circ} \mathrm{c}\right)$ than in the second month $\left(22-29^{\circ} \mathrm{C}\right)$.

- According to these results, Mitac was the most efficient of all tested treatments. However, It may has some side effects according to treatment with a fumigation strips of Apivrol (amitraz) which was used by Bah (1999) who found an increase mortality of $1-3$ day old larvae $(61 \%$ vrs. $83 \%$ for control). Also, Lupo and Gerling (1990) found that some bees left their hives. Henderson and Bowman (1988) recoded high adult bee mortality in package bees. The mixture of geranium, lemon, chamomile and mint was more efficient than the mixture of lemon, black cumin and mint and single oil. These results indicated that using mixture of essential oils is more suitable with cotton strips in control Varroa mite. Geranium oil was more efficient than lemon 
oil through all treatments during seven applications. Allam et al. (2003) found that the mixture of jasmine, neem and black cumin was the most efficient of all the tested mixtures and neem oil was the best. Also, Ismail et al. (2006) used geranium oil and found that mite infestation decreased from $32.67 \%$ to $26.67 \%$ with an average $21.4 \%$.

- Essential oils were safe to human and bees as residue in honey is low even after long term treatments. Terpenes (mainly mono-terpenes) were the main components of essential oils, making up about $90 \%$ of the total. Most essential oils were mixtures of more than 50 components and many essential oil components naturally occur in honey (Imdrof et al. 1999 \& Allam et al. 2003).

- Essential oils may be more efficient in colonies when used soaking cotton strips, but not by spraying, as in the latter bees were more excited because of possible disturbance in queen pheromone inside colonies. Nevertheless, resistance to essential oils possibly develops, as in the case of synthetic pesticides. Since oils mix poorly with water, addition of an emulsifier such as triton-x is necessary. The use of essential oils can not be considered as the panacea. Integrated pest management strategy includes the following items:

1- Cutting out of drone brood (after trapping Varroa).

2- Thermal treatment (expose apiaries to sunshine) Allam et al. (2003).

3- Application of essential oils(in cotton strips).

4- Cultural control by addition lemon oil or lemon juice to sugar solution.

5- Putting the colonies in citrus garden and cultivation of geranium or chamomile around apiaries (These new cultural control) added to IPM programme.

6- Good apicultural management practices.

7- Genetic improvement by using hybrid queens between A. mellifera carnica (drones) and A.mellifera lamerkii (virgins), could be an effective and reliable method for the control of Varroa destructor.

\section{REFERENCES}

Abd El-Fattah, M. A., Nour, M. E. and El-Shemy, A. A. M., 1991. Efficacy of chemical compounds to control varroa mite (Varroa jacobsoni Oud.) in honeybee colonies in Egypt. Egypt. J. Appl.sci., 6(12): 139-152.

Abo-Shady 1939. Principles of bees. A book published by Association of honeybee in Egypt.
Allam, S. F. M. 1999. Studies on the honeybee parasite Varroa jacobsoni. Ph.D.Thesis, Faculty of Agric., Cairo Univ., Egypt.

Allam, S. F. M., Hassan, M. F., Rezk, M. A. and Zaki, A. Y. 2000. Utilization essential oils and chemical substances alone or in combination against varroa mite (Varroa destructor), a parasite of honeybee. Insect pathogens and insect parastic Nematodes IOBC wprs Bulletin 26(1): 273-274.

Allam, S. F.; Hassan, M. F; Rizk, M. A. and Zaki, A. Y., 2004. Essential oils via feeding syrups for hybrid of Apis mellifera carnica to control Varoa mite (Varroa destructor) through biological aspects on drone brood during spring. Menoufia J. Agric. Res., Shebin El-Kom. 29 (6): 1396-1402.

Allam, S. F. M., Hassan, M. F., Rizk, M. A. and Zaki, A. Y. 2004. Comparison among certain natural products, formic acid and mavrik against varroa mite, Varroa destructor, a parasite of honeybee on two stocks of Apis mellifera in Egypt. Minufiya J. Agric. Res. 29 (6): 13871395.

Allam, S. F. M., Hassan, M. F., Rizk, M. A. and Zaki, A. Y. 2005. Seasonal fluctuations infestation levels of Varroa destructor on honeybee colonies in middle Egypt. Minufiya J. Agric. Res. 30(2):689-708.

Anderson, D. L. and Trueman, J. W. H. 2000. Varroa jacobsoni (Acari: varroidae) is more than one species. Exp. Appl. Acarol., 24: 165-189.

Bah, M. 1999. Influence of some anti-varroa drugs on bee brood. Medycyna weternaryjna. 55(11) 769-771.

Baxter, J. R.; Ibarra J.; Wilson, W. T.; Arther, R. G.; Kellerby, J. D. and Stewart, J., 1999. Amitraz or coumaphos efficacy tests in Guatemala for control of varroa jacobsoni in honeybee. Southwestern Entomological Society (Dec): 309-313.

Bienefeld, K. 1996. Factors affecting duration of the post-capping period in brood of the honeybee(Apis mellifera carnica) .J. Apic. Res., 35(1):11-17.

Clark, B.1997. Essential oils tested in Devon. Beekeeping. 63(5): 108-110.

De Jong, D. 1997. Mites: Varroa and other parasites of brood, In R.A. Morse and R. Nowogrodzki (ed.), Honeybee pests, predators, and diseases, $3^{\text {rd }}$ ed. Cornell University Press, Ithaca, N. Y., 279-327

De Jong, D., Morse, R. A., and Eickwort, G. C. 1982. Mite pests of honeybees. Annu. Rev. Entomol. 27: 229-252.

El-Shemy, A. A. M. 1997. Potential methods of controlling varroa mite (Varroa jacobsoni Oud.) 
without chemicals. J. Agri. Sci., Mansoura Univ., 22(12):4643-4653.

El-Shemy, A. A. M., Afifi, A. M., and Allam, S. F. 1995. Evaluation of some fluvalinate compounds and biotechnical methods to control Varroa mite (Varroa jacobsoni Oud.) in honeybee colonies under Giza (Egypt) conditions. $1^{\text {st }}$ Int. conf. of Pest Control, Mansoura, Egypt, Sept., 1995. 291-300.

El-shemy, A. A.; El-Bishlawy, Sh. M. O.; Oyoun L. E. M. and Allam S. F. 2001. Comparison between clov oil, some plant materials and apistan in controlling Varroa mite. Biological control conference, Dept. of Econe. Entmol. \& pest. Fac.Agric. Cairo univ.

Elzen, P. J.; Baxter, J. R.; Elzen, G. W.; Rivera, R. and Wilson, W. T. 2000. Evaluation of grapefruit essential oils for controlling Varroa jacobsoni and Acarapis woodi. Amer. Bee-J 2000, 140: (8) 666-668; 10 ref.

Fathy, H. M. and Fouly, A. H. 1993. The acaricidal effect of camphor oil on Varroa jacobsoni infesting honeybee in Egypt. J. Agric Sci., Mansoura Univ., 18 (12): 3698-3705.

Fathy H. M. and Fouly, A. H. 1995. The effect of some natural volatile oils to control the ectoparasitic mite Varroa jacobsoni infesting honeybee in Egypt $1^{\text {st }}$ Int. Conf. Pest Control, Mansoura, Egypt, Sept.,1995, 311-319.

Girodan, G. and Leporati, M. 1989. Field trials against Varroa jacobsoni with Apitol in "present status of Varratosis in Europe and Progress in Varroa Control". Edited by Cavallorar. Proc. of Meeting of the EX Exterts Group/udine Italy,28-30 Nov.1988.

Guzman, E. N.; Sanchez, A.; Page, R. E., Jr. and Garcia, T. 1996. Susceptibility of European and
Africanized honeybees (Apis mellifera L.) and their hybrids to Varroa jacobsoni Oud. Apidologie, 27: 93-103.

Henderson, C; Bowman, C. 1988. Tests of chemical control agent for Varroa jacobsoni in honey-bee packages. Africanized Honey Bees and Bee Mites. R. E. Page, Needham, G., Delfinado Baker, M. Chickester, UK, Ellis Horwood: 380-386.

Hoppe, H.; Pritter, W. and Elizabeth, W. C. 1989. The control of parasitic mites: Varroa jacobsoni, Acarapis woodi and Tropilaelaps clareae with formic acid Amr Bee J., 129:739-742.

Ifantidis, M. D. 1987. Varroa jacobsoni Oud. Aspects of biology and prospects of control. Aplicollore Moderno 1987, 78 (4): 135-145.

Imdorf, A.; Bogdanov, S.; Ibjez Ochoa, R.and Calderone, N. W. 1999. Use of essential oils for the control of Varroa jacobsoni Oud. in honey bee colonies. Apidologie 30: 209-228.

Ismail, A. M.; Ghoniemy, H. A. and Owayss, A. A. 2006. Combating honeybee Varroa mite by plant oils alone or in an IPM prgramme. The second conference on farm integrated pest management 16-18 Jan. 2006. Fac. Agric., Fayoum Univ., 172-186.

Kumova, U. 2001. The investigation on the effects of some chemicals used to control Varroa jacobsoni in Turkey. Turk-Veterinerlik-VeHayvancilik-Dergisi. 25 (4): 597-602.

Lupo, A. and Gerling, D. 1990. A comparison between the efficiency of summer treatments using formic acid and Taktic against Varroa jacobsoni in beehives. Apidologie 21(3): 261-267.

Wienands, A. 1988. The Varroa mite has spread over most the world. Amer. Bee. J., 128 (5): 358- 359 . 